\title{
Conservation and restoration in peopled landscapes in Oceania: opportunities and challenges
}

\author{
Heiko U. Wittmer (D) A, G, Victor Anton ${ }^{\text {A }}$, Monica A. M. Gruber (D) A, B, \\ Luke Ireland ${ }^{\mathrm{D}} \mathrm{C}$, Wayne Linklater ${ }^{\mathrm{D}} \mathrm{A}$, James C. Russell ${ }^{\mathrm{D}, \mathrm{E}}$ and \\ Danielle F. Shanahan (iD F \\ ${ }^{A}$ Centre for Biodiversity and Restoration Ecology, School of Biological Sciences, Victoria \\ University of Wellington, PO Box 600, Wellington 6140, New Zealand. \\ ${ }^{B}$ Pacific Biosecurity, Victoria Link Limited, Victoria University of Wellington, PO Box 1762, \\ Wellington 6140, New Zealand. \\ ${ }^{\mathrm{C}}$ Anangu Pitjantjatjara Yankunytjatjara Land Management, PMB 227, Umuwa via Alice Springs, \\ NT 0872, Australia. \\ ${ }^{D}$ School of Biological Sciences, University of Auckland, Private Bag 92019, Auckland 1142, \\ New Zealand. \\ EZero Invasive Predators, c/o Zealandia Sanctuary, PO Box 9267, Marion Square, Wellington \\ 6141, New Zealand. \\ ${ }^{\mathrm{F}}$ Centre for People and Nature, Zealandia, 31 Waiapu Road, Karori, Wellington, New Zealand. \\ GCorresponding author. Email: heiko.wittmer@vuw.ac.nz
}

\begin{abstract}
While the role of humans in causing high rates of species extinctions worldwide is well established, philosophies and opinions as to how to mitigate the current biodiversity loss are once again hotly debated topics. At the centre of the debate are differences in opinions regarding the value and the best methods of conserving and restoring biodiversity in peopled landscapes. Here we synthesise information from different case studies from Oceania that demonstrate how biodiversity conservation in peopled landscapes will require different, and often novel, socio-ecological approaches. We draw special attention to the importance of prioritising human dimensions in the conservation of different ecosystems, ranging from highly modified urban areas to largely intact wilderness areas. Particularly, we explore the importance of understanding motivations to conserve biodiversity, implementing well designed conservation actions, both socially and ecologically, and involving different stakeholders in the design and implementation of conservation projects. On the basis of our synthesis, we suggest that conservation in peopled landscapes in Oceania offers great opportunities for community involvement, including traditional landowners, in all aspects of conservation planning and implementation. Where uncertainties regarding the suitability of established management strategies exist, novel guidelines should be based on the best available ecological and social evidence to avoid potential negative outcomes.
\end{abstract}

Additional keywords: biodiversity, human dimensions, predator control, stakeholder involvement, urban areas

Received 20 September 2018, accepted 1 October 2018, published online 6 December 2018

\section{Introduction}

While the role of humans in causing high rates of species extinctions worldwide is well established (Dirzo et al. 2014), philosophies and opinions as to how to mitigate the current loss of biodiversity are once again hotly debated topics (e.g. Kareiva and Marvier 2012; Soule 2013). At the centre of the debate are perceived and real differences in the comparative value of natural wilderness areas versus human-modified landscapes for biodiversity conservation. What appears obvious is that an ever-increasing footprint associated with a human population approaching eight billion necessitates conservation and restoration approaches being directed at landscapes both inhabited and used by humans (e.g. Lindenmayer and Franklin 2002; Ives et al. 2016). The impact of humans on biodiversity in these 'peopled landscapes', however, varies in type (i.e. primary causes associated with observed population declines or species extinctions), intensity, and scale, and will thus likely require local and flexible approaches to achieve positive conservation outcomes.

Oceania is a diverse geographic region consisting of both large continental landmasses and numerous and often remote islands in the Pacific Ocean. Presently, Oceania is also home to 
over 40 million people (United Nations 2017). While overall population density is lower than in all other geographic regions with the exception of Antarctica, it can be very high locally. For example, levels of urbanisation in Oceania are among the highest in the world (e.g. 90\% in Australia, 86\% in New Zealand, 95\% in Guam: The World Bank 2017). The historical impact of humans on the environment also varies dramatically across Oceania. Specifically, the region is home to the longest genetically isolated human population (i.e. indigenous Australians: Rasmussen et al. 2011), a continental landmass, isolated for $>70$ million years, and only settled by humans $\sim 750$ years ago (i.e. New Zealand: Wilmshurst et al. 2011), and diverse oceanic archipelagos with varying levels of human habitation and influence. Furthermore, there are substantial differences across Oceania with respect to impacts of European colonisation, including the acceptance of conservation approaches by traditional landowners, standard of living, which is considerably lower for people on Pacific Islands, type and intensity of land use (e.g. industry and agriculture) as well as regional extinction rates (e.g. Recher and Calver 2004). On the basis of this diversity, Oceania is an ideal region to explore opportunities and challenges to conserve and restore biodiversity in peopled landscapes.

Our objectives for contributions to this special issue were three-fold. First, we wanted to present case studies covering much of the Oceania geographic region (spatial representation). Second, we wanted to explore opportunities and challenges across gradients in human impact ranging from highly modified (and densely populated) urban areas to largely intact wilderness areas and National Parks. Third, recognising the current debate about the role of people in conserving biodiversity, we wanted to explore both the ecological and social challenges associated with biodiversity conservation in Oceania. This necessitates considering the needs and roles of all residents of its landscapes, including engagement of traditional landowners. Combined, the contributions highlight that the opportunities for conserving or restoring biodiversity to human-modified landscapes have not yet been taken full advantage of (Table 1). The contributions also emphasise that the challenges of biodiversity conservation in peopled landscapes require different, and often novel, approaches that integrate both social and ecological perspectives. Here we discuss special issue contributions in three separate categories: (1) conservation in urban areas, (2) control of invasive species in peopled landscapes, and (3) stakeholder involvement for conservation actions in protected areas.

\section{Conservation in urban areas}

Cities currently represent $<1 \%$ of the earth's land surface (Schneider et al. 2010), yet more than $50 \%$ of all people worldwide already live in these landscapes (World Health Organisation 2016). The value of urban areas for biodiversity conservation, however, is often overlooked. Cities are among the most highly modified habitats, characterised by a large proportion of artificial structures (McPhearson et al. 2016), interspersed by small and fragmented patches of remaining vegetation (Aronson et al. 2014). These modifications have affected biodiversity patterns in surprisingly similar ways. Specifically, many groups of species, such as birds, have become homogenised in urban areas with generalists dominating the resulting communities
(McKinney 2006). In addition, many non-native and invasive species have become firmly established in urban areas, where they now interact with native species in both positive and negative ways. Despite the substantial habitat modifications and establishment of novel communities, cities can still host many endemic species, including those threatened with extinction (Aronson et al. 2014). Managing for species conservation in urban environments not only offers opportunities for conservation but also educates people about the importance and value of local biodiversity (McKinney 2006).

Urban environments in Oceania provide many opportunities that can benefit biodiversity conservation, both through community-led action and national and local government effort. There is significant opportunity to enhance effort on both fronts. For example, due to the large number of potential volunteers, environmental community groups can make invaluable contributions to conservation and restoration projects in urban environments (Peters et al. 2016), including help control invasive species (Gaertner et al. 2017), and analyse monitoring data (Anton et al. 2018). Furthermore, urban gardens, in particular, offer opportunities for habitat enhancement and subsequent biodiversity increases (Lin et al. 2015). These efforts can feed into government-led programs of work that generate landscapelevel outcomes.

In this special issue of Pacific Conservation Biology we compiled three studies that investigate different aspects of the design and implementation of successful conservation programs in urban environments. First, Shanahan et al. (2018) discuss the motivations for conservation in Oceania and highlight opportunities for harnessing effort. Second, van Heezik and Seddon (2018) explore the motivation and potential for species reintroductions into urban environments as a conservation tool. Lastly, Linklater et al. (2018) evaluate and discuss best practice for species reintroductions in cities.

The first step in harnessing energy to protect or restore urban biodiversity is to understand motivations for conservation; this understanding is vital to ensure that actions are effective and maximise outcomes. To understand motivations for conservation, Shanahan et al. (2018) evaluated publicly available urban biodiversity conservation strategies from 12 cities across Australia $(n=7)$ and New Zealand $(n=5)$ ranging in population size from $\sim 50000$ to over 5 million people. In addition, the authors surveyed five biodiversity strategies from Pacific Islands. From these documents they extracted information that allowed them to develop broader categories as to why strategies were developed in the first place: (1) protecting ecosystem services, (2) addressing declines of biodiversity, and meeting (3) ethical and (4) statutory responsibilities.

Despite some differences across regions, local biodiversity strategies highlight that ecosystem services and benefits for people remain the key motivators for implementing conservation actions (Shanahan et al. 2018). Given recent findings of links between experiencing nature in various ways and human well-being (e.g. Shanahan et al. 2015), these results give cities in Oceania a clear mandate to continue investing in conservation strategies.

Concerns for biodiversity, on the other hand, were important motivators in New Zealand (100\% of strategies assessed) but much less so in the Pacific Islands (60\%) and Australia (40\%). 


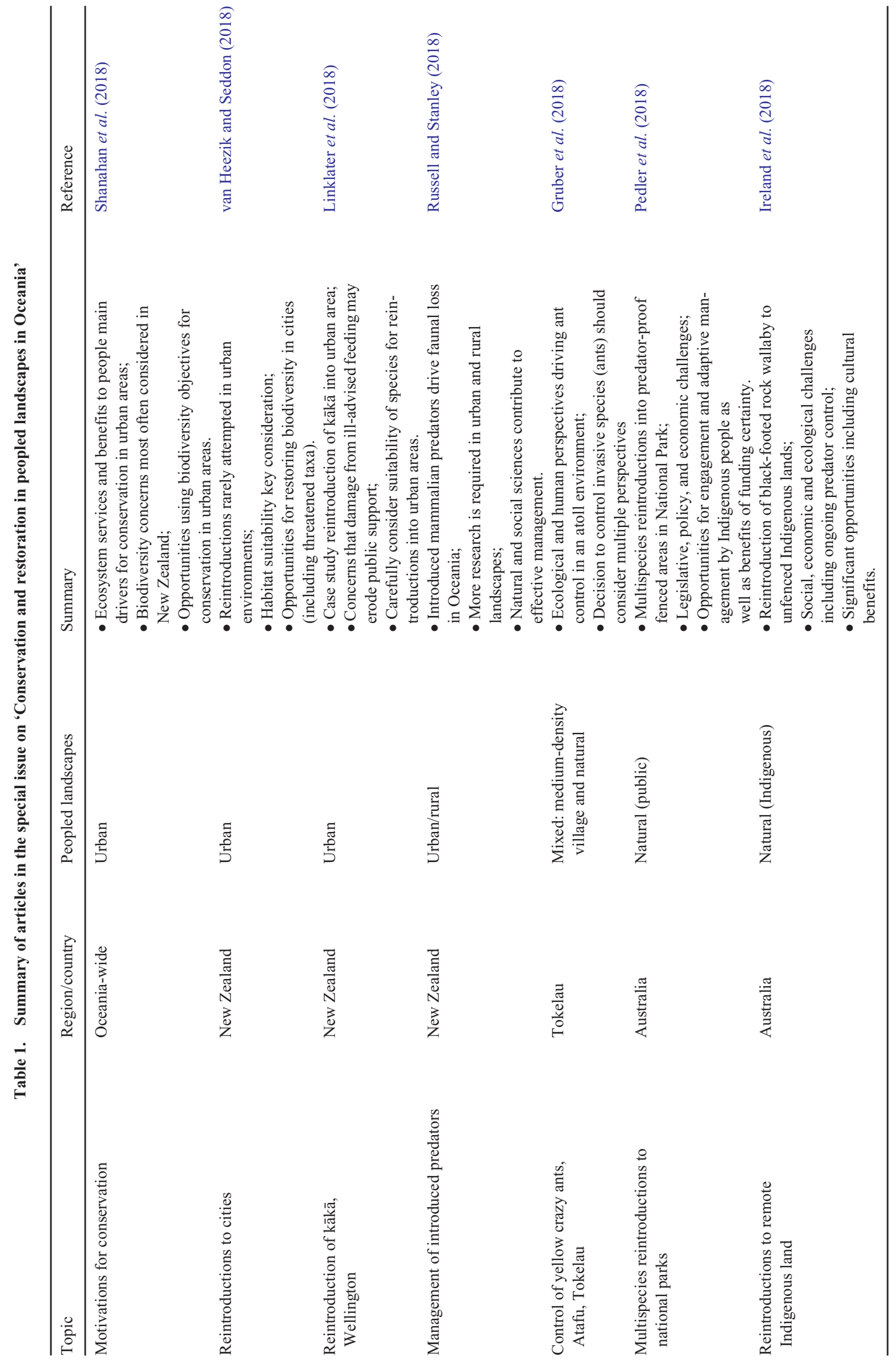


The apparent differences between New Zealand and Australia are particularly surprising given the similarities in development and standard of living in the two countries. Also, despite the known potential to conserve biodiversity - including endangered species - in urban areas (e.g. Ives et al. 2016) these results suggest that cities across much of Oceania are not yet contributing as much as they potentially could to biodiversity conservation.

More importantly, variation in motivation to conserve biodiversity among regions in Oceania suggests that localised approaches to education and conservation implementation are ultimately necessary. Specifically, the findings of Shanahan et al. (2018) provide city managers with opportunities to develop novel frameworks for biodiversity conservation that incorporate differences in values. For example, in New Zealand it might be sufficient to emphasise increases in urban biodiversity associated with proposed strategies (ecocentrism) while strategies on Pacific Islands and Australia might be more effective by emphasising direct and indirect benefits for humans (anthropocentrism).

On the basis of dissimilarities in development and living standards, differences between Australia and New Zealand, on the one hand, and island nations, on the other, were to be expected. What is surprising is that these results (i.e. greatest differences appeared independent of development) indicate that other issues significantly influence motivations (or the lack thereof) for conservation.

Another crucial step to protecting or restoring urban biodiversity is to identify conservation tools that are well suited to achieve the desired conservation goals. Given the high motivation and potential for biodiversity conservation in cities in New Zealand, van Heezik and Seddon (2018) explore whether we should use species reintroductions into urban environments as a conservation tool. While many examples exist worldwide of rare and endangered species occurring and indeed thriving in cities (see references in van Heezik and Seddon 2018), only seven of 182 reviewed animal reintroductions involved releases into urban areas.

Based on an expert survey, van Heezik and Seddon (2018) provide a list of species (including 15 forest birds) potentially suitable for reintroduction to urban areas in New Zealand. Reintroductions, however, should only be considered if several key factors have been addressed or met. These include (1) increasing habitat restoration in cities (Clarkson and Kirby 2016) as habitat loss is a major limiting factor for many native forest bird species in New Zealand; (2) social acceptability and willingness to implement changes needed to make cities more suitable habitats for wild species, including, for example, management of domestic pets such as cats (Kikillus et al. 2017); and (3) intensive and widespread control of invasive predators (i.e. the primary causes of the initial local extinction). The latter is particularly important as all suitable bird reintroduction candidates are threatened by predation from invasive mammals across their distribution in New Zealand.

A large contributor to the perceived suitability for reintroduction in urban areas is the recent and widespread commitment to controlling invasive mammals - namely rats, possums and mustelids across New Zealand (e.g. the 'Predator Free New Zealand' initiative). Much of the control of invasive species in urban areas can be achieved by trapping efforts initiated and managed by local community groups. Advantages include cost effectiveness and a scale of control efforts that would be difficult to attain without volunteers and citizen scientists. Including the public in invasive species management is also important given the variability among people in acceptance of lethal and nonlethal control methods used to reduce and eradicate invasive mammals (Dubois et al. 2017), as well as the necessity to conduct control efforts over long periods. Effective monitoring could also be aided by citizen scientists (Anton et al. 2018), ultimately leading to an improved understanding of the feasibility and value of reintroducing endangered species into urban areas. Such data are not yet readily available and thus support previous calls to treat reintroductions as experiments and opportunities for gaining ecological knowledge (Seddon et al. 2007).

Compared with uninhabited landscapes, conservation efforts and species reintroductions to cities occur in a more complex, people-dominated social, economic and ecological system. Linklater et al. (2018) thus draw attention to the importance of prioritising the human dimensions of wildlife introductions. They illustrate the 'pitfalls' to be avoided and the best-practice possible using the reintroduction of kākā (Nestor meridionalis), a large social parrot, to Wellington City. From household surveys of Wellington City residents, the authors show that the reintroduction of kākā has initiated a human-wildlife conflict because some birds damage private and public property. Feeding of kākā by residents is shown to intensify the damage and lead to a polarisation of attitudes amongst residents. Thus, a human-wildlife conflict becomes an even more serious, human-human conflict over kākā. While quantifying the problem and illustrating how it might have been avoided, the authors provide remedies too. For example, the paper outlines the usefulness of the concept of 'social capacity', alongside 'ecological capacity' for deciding on urban reintroductions.

\section{Control of invasive species in peopled landscapes}

Some populations of introduced species can become invasive and, among other impacts, cause species extinctions (e.g. Blackburn et al. 2004). As invasive species are typically not perceived as a problem until their effects are strongly felt, prevention through biosecurity is often not a high priority, particularly in developing countries. Although biosecurity in developed countries such as New Zealand and Australia is significantly more advanced, these countries have well established populations of invasive species. As a consequence, the most used management tool for invasive species is lethal removal (Doherty and Ritchie 2017), often using pesticides, or trapping and shooting in the case of larger mammals.

The control of invasive species is a conservation approach that has received increasing attention in Oceania, particularly where mammals have been controlled for the protection and recovery of endemic fauna (e.g. Russell et al. 2017) and flora (e.g. Wolf et al. 2018). Much of our current understanding of the positive biodiversity effects of eradication in Oceania comes from invasive mammal eradications on offshore islands, often reserves or National Parks, resulting in positive conservation outcomes (e.g. Jones et al. 2016; Russell et al. 2017; Wolf et al. 
2018). However, these areas are often uninhabited by people or inhabited at very low density.

The control of invasive mammals and other invasive species in more densely inhabited areas provide unique challenges, particularly regarding the acceptability of using pesticides, and killing for conservation in general, and the logistics of operations. One example of the unique ecological and social challenges in urban environments is to assess the impact of companion animals on biodiversity and to propose management solutions informed by science that are acceptable to the broader public.

Russell and Stanley (2018) provide a broad overview of opportunities for invasive mammal control in peopled landscapes in New Zealand. Their review summarising our current understanding of predator management in peopled landscapes of New Zealand highlights the unique opportunities for biodiversity protection in inhabited environments. For example, initiatives such as 'Predator Free New Zealand' provide additional opportunities for the general public to get directly involved in management aimed at restoring biodiversity in cities. This can be through a range of activities, including the organised local trapping of invasive species such as rats and mustelids by local community groups, controlling the movements of companion animals, and contributing to the analysis of monitoring data (Anton et al. 2018). Positive ecological and social outcomes of invasive species management need to be demonstrated via effective monitoring to ethically justify control efforts (Dubois et al. 2017).

In Oceania mammals, particularly rats, are the species most often targeted for eradication. However, another major pest group are introduced ants. Of the five ant species listed among a selection of the 'world's worst invasive species' (Lowe et al. 2004), Australia already has all five, while most Pacific Islands have at least three (Gruber et al. 2017). These ants can sometimes cause large changes in ecological communities (O'Dowd et al. 2003). New Zealand maintains comprehensive biosecurity protocols to minimise the threat of these ants establishing there, including a hygiene system for sea containers (the major pathway for entry: Ashcroft et al. 2008) and a recurrent nationwide ant survey (e.g. Peacock et al. 2015).

Gruber et al. (2018) focus on a fine-scale case study of ant control in the territory of Tokelau, and provide an example of an approach that considered both ecological and social perspectives to decide whether to control invasive yellow crazy ants (Anoplolepis gracilipes). During field trials, researchers first quantified the distribution and abundance of yellow crazy ants to establish baseline data needed to define the problem. Ant surveys were followed by studies aimed at understanding the potential negative effects of yellow crazy ants on invertebrate communities and local seabird populations. Results from these follow-up studies suggested that white terns (Gygis alba) were sensitive to negative effects even at relatively low abundances of yellow crazy ants.

Ecological impact assessments were followed by qualitative surveys (interviews). Survey respondents were particularly concerned about the possible negative impact on all aspects of their lives once yellow crazy ants became established. Concerns included perceived effects on food production and storage, harm to other species, both domestic and wild, and to the people themselves. At the same time, residents did not voice concerns about the potential use of pesticides to control ant populations.

Based on outcomes from the ecological impact assessments and the surveys gauging people's concerns and attitudes, the decision was made to control ants using pesticides. Notably, potential funders cited the survey of people's opinions as a major component to their decision to fund control work. The study serves as an example for community engagement in the development of suitable and acceptable control efforts of invasive species in the Pacific Islands. It could serve as a model for developing invasive pest control efforts in peopled landscapes across other regions in Oceania.

\section{Stakeholder involvement for conservation actions in protected areas}

Conserving biodiversity in protected areas such as national parks is a mainstay of conservation biology worldwide (e.g. White et al. 2013). Protected areas essentially function by separating the impact of people on biodiversity by managing, for example, access, hunting, or (for-profit) use of environmental resources. Traditionally, protected areas were established in areas with much lower human densities and impact, including remote wilderness areas. Despite our best efforts, biodiversity within protected areas is often at risk from human actions in surrounding landscapes (Brashares et al. 2004). In addition, wildlife moving into landscapes used by people outside protected areas can occasionally affect their livelihoods (White et al. 2013). The resulting conflict has the potential to erode support from local communities for protected areas.

Protected areas, particularly large ones, can help conserve species that are otherwise difficult to maintain in peopled landscapes. This includes species with large area requirements such as carnivores. The intensive management needed to maintain biodiversity in protected areas is costly and thus necessitates the need for involvement of different stakeholders, even in landscapes with low population densities. The involvement of different stakeholders, however, can increase the complexity of the design and management of protected areas, particularly if there are unresolved issues of traditional landownership (Sterling et al. 2017).

Oceania has a large network of protected areas, both in marine and terrestrial environments, intended to safeguard its highly endemic faunas and floras from extinction. However, a wide range of processes (i.e. the overwhelming impact of invasive species, climate change and overexploitation) threaten the effectiveness and efficiency of the protected areas in this region (Kingsford et al. 2009). Furthermore, the pressure posed by humans on protected areas of Oceania is expected to increase more than in other regions of the world. For example, the spatial distance between protected areas and cities in Oceania is expected to decrease by $17 \mathrm{~km}$ by 2030 when compared with 1995, which is more than double the average distance worldwide (Mcdonald et al. 2008). To highlight how managers of protected areas can overcome the ecological and social challenges associated with biodiversity conservation in remote areas, Ireland et al. (2018) and Pedler et al. (2018) discuss two case studies.

Ireland et al. (2018) focus on the challenges and opportunities associated with reintroducing threatened species to lands 
managed by Indigenous people, which occupy over $20 \%$ of the Australian landmass. They outline the planning and logistical issues as well as project costs that helped ensure support for the reintroduction of threatened black-footed rock-wallabies (warru, Petrogale lateralis) from traditional owners. The authors conclude that large-scale conservation efforts on land managed by Indigenous people not only provides significant opportunities for biodiversity conservation but help further cultural opportunities and improved livelihoods for often disadvantaged communities by providing opportunities for employment and training.

While Ireland et al. (2018) report on a case study from Australia, including Indigenous people in the conservation and management of land and resources also has relevance and tradition in New Zealand. For example, a range of reintroduction projects in New Zealand incorporate close partnership between conservation professionals and Māori groups due to the special status or taonga held by many endemic species (e.g. Harms 2015), and the ownership of lands by Māori. In addition, the New Zealand government is in active negotiations with many Māori groups (iwi) to settle grievances against the Treaty of Waitangi - often involving land claims. A recent example of how such settlements can increase involvement of Māori in conservation and resource management involves the former Te Urewera National Park. Specifically, as part of a settlement with the Tūhoe iwi, Te Urewera ceased to be a National Park in 2014 to allow joint management by the iwi and the government. This allows for management objectives to include future Tūhoe resource use inside the protected area while Tūhoe continue to allow and support biodiversity conservation on their lands.

Pedler et al. (2018) summarise results from a project aimed at reintroducing seven locally extinct marsupials into Stewart National Park, New South Wales, Australia. As a national park, the land is managed by governmental organisations. Due to the negative impact of introduced predators, the reintroduction could only go ahead once two predator exclosures had been erected. Construction and maintenance of fence infrastructure is costly and governed by increasingly complex legislation. Due to the large scale of the project, it not only required ecological impact assessments but significant stakeholder involvement including that of both traditional and non-traditional landowners. The information provided by the authors further highlights legislative and economic challenges. More importantly, the study emphasises the advantages of government-driven conservation projects in remote areas including funding certainty needed for large-scale and long-term projects. Engagement from traditional and non-traditional landowners and other stakeholders, however, will be needed for such strategies to succeed.

\section{Conclusions}

Given the overwhelming impact of humans on current high rates of species extinctions worldwide, developing novel conservation and restoration strategies that embrace opportunities in peopled landscapes are required. This is particularly topical in Oceania, an area with highly endemic faunas and floras and among the highest rates of species extinctions (e.g. Duncan et al. 2013). Conservation strategies will need to integrate social and ecological perspectives to account for differences in values among peoples and to reflect variation in issues along urban, rural and wilderness gradients. Current methods, including those used to monitor and manage invasive species, need to be adapted so they can be effectively used in peopled landscapes. This provides great opportunities for community-led initiatives but also poses challenges that should not be underestimated. At the same time, however, government commitment to conservation should expand and embrace stakeholder involvement including with traditional landowners.

Opportunities exist to significantly broaden human involvement in all aspects of conservation planning and implementation. Opportunities for community involvement include problem identification as well as project design, implementation, monitoring, data analysis and dissemination of results (e.g. Peters et al. 2016; Anton et al. 2018). Increasing community involvement will require rethinking traditional conservation approaches including being proactive about resolving or preventing human-wildlife conflict that is likely to increase due to greater differences in opinions in peopled landscapes (Redpath et al. 2013). Finally, uncertainties exist when trying to expand conservation into peopled landscapes. This may sometimes require taking a precautionary approach that offers opportunities for learning and adapting conservation and restoration strategies as projects move along.

\section{Conflict of interest}

The authors declare no conflicts of interest

\section{Acknowledgements}

VA is thankful for a CBRE scholarship to attend the 2018 Society for Conservation Biology Oceania meeting in Wellington. This research did not receive any specific funding

\section{References}

Anton, V., Hartley, S., Geldenhuis, A., and Wittmer, H. U. (2018). Monitoring the mammalian fauna of urban areas using remote cameras and citizen science. Journal of Urban Ecology 4, juy002. doi:10.1093/ JUE/JUY002

Aronson, M. F. J., La Sorte, F. A., Nilon, C. H., Katti, M., Goddard, M. A., Lepczyk, C. A., Warren, P. S., Williams, N. S. G., Cilliers, S., Clarkson, B., Dobbs, C., Dolan, R., Hedblom, M., Klotz, S., Kooijmans, J. L., Kühn, I., MacGregor-Fors, I., McDonnell, M., Mörtberg, U., Pyšek, P., Siebert, S., Sushinsky, J., Werner, P., and Winter, M. (2014). A global analysis of the impacts of urbanization on bird and plant diversity reveals key anthropogenic drivers. Proceedings of the Royal Society B: Biological Sciences 281, 20133330. doi:10.1098/RSPB.2013.3330

Ashcroft, T. T., Nendick, D., O'Connor, S. M., Sarty, M., Gunawardana, D., and Weston, G. (2008). Managing the risk of invasive exotic ants establishing in New Zealand. New Zealand Ministry of Primary Industries.

Blackburn, T. M., Cassey, P., Duncan, R. P., Evans, K. L., and Gaston, K. J. (2004). Avian extinction and mammalian introductions on oceanic islands. Science 305, 1955-1958. doi:10.1126/SCIENCE.1101617

Brashares, J. S., Arcese, P., Sam, M. K., Coppolillo, P. B., Sinclair, A. R. E., and Balmford, A. (2004). Bushmeat hunting, wildlife declines, and fish supply in West Africa. Science 306, 1180-1183. doi:10.1126/SCIENCE. 1102425

Clarkson, B. D., and Kirby, C. L. (2016). Ecological restoration in urban environments in New Zealand. Ecological Management \& Restoration 17, 180-190. doi:10.1111/EMR.12229 
Dirzo, R., Young, H. S., Galetti, M., Ceballos, G., Isaac, N. J. B., and Collen, B. (2014). Defaunation in the Anthropocene. Science 345, 401-406. doi:10.1126/SCIENCE. 1251817

Doherty, T. S., and Ritchie, E. G. (2017). Stop jumping the gun: a call for evidence-based invasive predator management. Conservation Letters 10, 15-22. doi:10.1111/CONL.12251

Dubois, S., Fenwick, N., Ryan, E. A., Baker, L., Baker, S. E., Beausoleil, N J., Carter, S., Cartwright, B., Costa, F., Draper, C., Griffin, J., Grogan, A., Howald, G., Jones, B., Littin, K. E., Lombard, A. T., Mellor, D. J., Ramp, D., Schuppli, C. A., and Fraser, D. (2017). International consensus principles for ethical wildlife control. Conservation Biology 31, 753760. doi:10.1111/COBI.12896

Duncan, R. P., Boyer, A. G., and Blackburn, T. M. (2013). Magnitude and variation of prehistoric bird extinctions in the Pacific. Proceedings of the National Academy of Sciences of the United States of America 110, 6436-6441. doi:10.1073/PNAS.1216511110

Gaertner, M., Wilson, J. R. U., Cadotte, M. W., MacIvor, J. S., Zenni, R. D., and Richardson, D. M. (2017). Non-native species in urban environments: patterns, processes, impacts and challenges. Biological Invasions 19, 3461-3469. doi:10.1007/S10530-017-1598-7

Gruber, M. A. M., Cooling, M., and Burne, A. R. (2017). An invasive ant distribution database to support biosecurity risk analysis in the Pacific. Pacific Conservation Biology 23, 258-261. doi:10.1071/ PC17004

Gruber, M. A. M., Pierce, R. J., Burne, A. R., Naseri-Sale, L., and Lester, P. J. (2018). Using community engagement and biodiversity surveys to inform decisions to control invasive species: a case study of yellow crazy ants in Atafu, Tokelau. Pacific Conservation Biology 24, 379-387. doi:10.1071/PC17055

Harms, M. S. (2015). Assertions of cultural autonomy: indigenous Maori knowledge in New Zealand's community-based Maungatautari Ecoisland project. Global Bioethics 26, 145-158. doi:10.1080/11287462. 2015.1039249

Ireland, L., Zabek, M., Galindes-Silva, C., Weir, S., West, R., Olds, L., Backhouse, B., Copley, P., and Read, J. (2018). More than just animals: opportunities and costs of reintroducing threatened black-footed rockwallabies to remote Indigenous land. Pacific Conservation Biology 24, 388-396. doi:10.1071/PC17059

Ives, C. D., Lentini, P. E., Threlfall, C. G., Ikin, K., Shanahan, D. F., Garrard, G. E., Bekessy, S. A., Fuller, R. A., Mumaw, L., Rayner, L., Rowe, R. Valentine, L. E., and Kendal, D. (2016). Cities are hotspots for threatened species. Global Ecology and Biogeography 25, 117-126. doi:10. 1111/GEB. 12404

Jones, H. P., Holmes, N. D., Butchart, S. H. M., Tershy, B. R., Kappes, P. J., Corkery, I., Aguirre-Muñoz, A., Armstrong, D. P., Bonnaud, E., Burbidge, A. A., Campbell, K., Courchamp, F., Cowan, P. E., Cuthbert, R. J., Ebbert, S., Genovesi, P., Howald, G. R., Keitt, B. S., Kress, S. W., Miskelly, C. M., Oppel, S., Poncet, S., Rauzon, M. J., Rocamora, G., Russell, J. C., Samaniego-Herrera, A., Seddon, P. J., Spatz, D. R., Towns, D. R., and Croll, D. A. (2016). Invasive mammal eradication on islands results in substantial conservation gains. Proceedings of the National Academy of Sciences of the United States of America 113, 4033-4038. doi:10.1073/PNAS.1521179113

Kareiva, P., and Marvier, M. (2012). What is conservation science? Bioscience 62, 962-969. doi:10.1525/BIO.2012.62.11.5

Kikillus, K. H., Chambers, G. K., Farnworth, M. J., and Hare, K. M. (2017). Research challenges and conservation implications for urban cat management in New Zealand. Pacific Conservation Biology 23, 15-24. doi:10.1071/PC16022

Kingsford, R. T., Watson, J. E., Lundquist, C. J., Venter, O., Hughes, L., Johnston, E. L., Atherton, J., Gawel, M., Keith, D. A., Mackey, B. G., and Morley, C. (2009). Major conservation policy issues for biodiversity in Oceania. Conservation Biology 23, 834-840. doi:10.1111/J.1523-1739. 2009.01287.X
Lin, B. B., Philpott, S. M., and Jha, S. (2015). The future of urban agricultural and biodiversity-ecosystem services: challenges and next steps. Basic and Applied Ecology 16, 189-201. doi:10.1016/J.BAAE.2015.01.005

Lindenmayer, D. B., and Franklin, J. F. (2002). 'Conserving Forest Biodiversity: a Comprehensive Multiscaled Approach.' (Island Press: Washington.)

Linklater, W., Chapman, H., Gregor, A., Calder-Flynn, R., Gouws, J., Quigan, O., Rustandi, A., Brian-Molitaviti, J., and Ying, Y. (2018). Initiating a conflict with wildlife - the reintroduction and feeding of kākā, Wellington City, New Zealand. Pacific Conservation Biology 24 360-370. doi:10.1071/PC18005

Lowe, S., Browne, M., and Boudjelas, S. (2004). 100 of the world's worst invasive alien species - a selection from the Global Invasive Species database. The Invasive Species Specialist Group (ISSG) of the Species Survival Commission (SSC) of the World Conservation Union (IUCN), Gland, Switzerland.

Mcdonald, R. I., Kareiva, P., and Forman, R. T. (2008). The implications of current and future urbanization for global protected areas and biodiversity conservation. Biological Conservation 141, 1695-1703. doi:10. 1016/J.BIOCON.2008.04.025

McKinney, M. L. (2006). Urbanization as a major cause of biotic homogenisation. Biological Conservation 127, 247-260. doi:10.1016/J.BIO CON.2005.09.005

McPhearson, T., Pickett, S. T. A., Grimm, N. B., Niemela, J., Alberti, M., Elquist, T., Weber, C., Haase, D., Breuste, J., and Qureshi, S. (2016) Advancing urban ecology toward a science of cities. Bioscience 66, 198212. doi:10.1093/BIOSCI/BIW002

O'Dowd, D. J., Green, P. T., and Lake, P. S. (2003). Invasional 'meltdown' on an oceanic island. Ecology Letters 6, 812-817. doi:10.1046/J.14610248.2003.00512.X

Peacock, L., Mattson, L., Craddock, P., and Pettigrew, J. (2015). National invasive ant surveillance programme annual report 2015. Surveillance 42, 63-64. (New Zealand Ministry of Primary Industries.) Available at: http://www.sciquest.org.nz/node/111120 [verified 16 October 2018]

Pedler, R. D., West, R. S., Read, J. L., Moseby, K. E., Letnic, M., Keith, D. A., Leggett, K. D., Ryall, S. R., and Kingsford, R. T. (2018). Conservation challenges and benefits of multispecies reintroductions to a national park - a case study from New South Wales, Australia. Pacific Conservation Biology 24, 397-408. doi:10.1071/PC17058

Peters, M. A., Hamilton, D., Eames, C., Innes, J., and Mason, N. W. H. (2016). The current state of community-based environmental monitoring in New Zealand. New Zealand Journal of Ecology 40, 279-288. doi:10. 20417/NZJECOL.40.37

Rasmussen, M., Guo, X., Wang, Y., Lohmueller, K. E., Rasmussen, S., Albrechtsen, A., Skotte, L., Lindgreen, S., Metspalu, M., Jombart, T., Kivisild, T., Zhai, W., Eriksson, A., Manica, A., Orlando, L., De La Vega, F. M., Tridico, S., Metspalu, E., Nielsen, K., Ávila-Arcos, M. C., Moreno-Mayar, J. V., Muller, C., Dortch, J., Gilbert, M. T. P., Lund, O., Wesolowska, A., Karmin, M., Weinert, L. A., Wang, B., Li, J., Tai, S., Xiao, F., Hanihara, T., Van Driem, G., Jha, A. R., Ricaut, F.-X., De Knijff, P., Migliano, A. B., Romero, I. G., Kristiansen, K., Lambert, D. M., Brunak, S., Forster, P., Brinkmann, B., Nehlich, O., Bunce, M., Richards, M., Gupta, R., Bustamante, C. D., Krogh, A., Foley, R. A., Lahr, M. M., Balloux, F., Sicheritz-Pontén, T., Villems, R., Nielsen, R., Wang, J., and Willerslev, E. (2011). An Aboriginal Australian genome reveals separate human dispersals into Asia. Science 334, 94-98. doi:10. 1126/SCIENCE.1211177

Recher, H. F., and Calver, M. (2004). Conservation biology in the Pacific. Conservation Biology 18, 1449-1451. doi:10.1111/J.1523-1739.2004. 01861.X

Redpath, S. M., Young, J., Evely, A., Adams, W. M., Sutherland, W. J., Whitehouse, A., Amar, A., Lambert, R. A., Linnell, J. D. C., Watt, A. and Gutierrez, R. J. (2013). Understanding and managing conservation 
conflicts. Trends in Ecology \& Evolution 28, 100-109. doi:10.1016/J. TREE.2012.08.021

Russell, J. C., and Stanley, M. C. (2018). An overview of introduced predator-management in inhabited landscapes. Pacific Conservation Biology 24, 371-378. doi:10.1071/PC18013

Russell, J. C., Meyer, J.-Y., Holmes, N. D., and Pagad, S. (2017). Invasive alien species on islands: impacts, distribution, interactions and management. Environmental Conservation 44, 359-370. doi:10.1017/ S0376892917000297

Schneider, A., Friedl, M. A., and Potere, D. (2010). Mapping global urban areas using MODIS 500-m data: new methods and datasets based on 'urban ecoregions'. Remote Sensing of Environment 114, 1733-1746. doi:10.1016/J.RSE.2010.03.003

Seddon, P. J., Armstrong, D. P., and Maloney, R. (2007). Developing the science of reintroduction biology. Conservation Biology 21, 303-312. doi:10.1111/J.1523-1739.2006.00627.X

Shanahan, D. F., Fuller, R. A., Bush, R., Lin, B. B., and Gaston, K. J. (2015). The health benefits of urban nature: how much do we need? Bioscience 65, 476-485. doi:10.1093/BIOSCI/BIV032

Shanahan, D. F., Ledington, J. E., and Maseyk, F. J. F. (2018). Motivations for conservation action in peopled landscapes. Pacific Conservation Biology 24, 341-348. doi:10.1071/PC18010

Soulé, M. (2013). The "New Conservation". Conservation Biology 27, 895897. doi:10.1111/COBI.12147

Sterling, E. J., Betley, E., Sigouin, A., Gomez, A., Toomey, A., Cullman, G., Malone, C., Pekor, A., Arengo, F., Blair, M., Filardi, C., Landrigan, K., and Porzecanski, A. L. (2017). Assessing the evidence for stakeholder engagement in biodiversity conservation. Biological Conservation 209 , 159-171. doi:10.1016/J.BIOCON.2017.02.008

The World Bank (2017). The United Nations Population Division's world urbanization projects: urban population ( $\%$ of total). The World Bank, Washington DC.

United Nations (2017). World population prospects: the 2017 revision, key findings and advance tables. Department of Economic and Social Affairs, Population Division ESA/P/WP/248. Available at: https://esa. un.org/unpd/wpp/Publications/

van Heezik, Y., and Seddon, P. J. (2018). Animal reintroductions in peopled landscapes: moving towards urban-based species restorations in New Zealand. Pacific Conservation Biology 24, 349-359. doi:10.1071/PC18026

White, P. J., Garrott, R. A., and Plumb, G. E. (2013). 'Yellowston's Wildlife in Transition.' (Harvard University Press.)

Wilmshurst, J. M., Hunt, T. L., Lipo, C. P., and Anderson, A. J. (2011). Highprecision radiocarbon dating shows recent and rapid initial human colonization in East Polynesia. Proceedings of the National Academy of Sciences of the United States of America 108, 1815-1820. doi:10. 1073/PNAS.1015876108

Wolf, C. A., Young, H. S., Zilliacus, K. M., Wegmann, A. S., McKown, M., Holmes, N. D., Tershy, B. R., Dirzo, R., Kropidlowski, S., and Croll, D. A. (2018). Invasive rat eradication strongly impacts plant recruitment of a tropical atoll. PLoS One 13, e0200743. doi:10.1371/JOURNAL. PONE.0200743

World Health Organisation (2016). Urban health. Global health observatory data. Available at: http://www.who.int/gho/urban_health/en/ 